\title{
LEGAL INTERPRETIVISM*
}

\author{
INTERPRETATIVISMO JURÍDICO
}

Nicos STAVROPOULOS**

\section{Resumen:}

El interpretativismo sobre el derecho ofrece una explicación filosófica del impacto que tiene la práctica institucional - las acciones jurídicas relevantes y prácticas de las instituciones políticas - sobre los derechos y obligaciones jurídicas. Explica la forma en que la práctica institucional que afecta al derecho es determinada por ciertos principios, identificados a través de la interpretación, que explican por qué la práctica debe tener ese papel. En este artículo distingo entre interpretativismo híbrido, el cual ha sido extensamente discutido en la literatura, y una versión no-híbrida que considero ha sido completamente ignorada. La principal diferencia entre las dos versiones es el papel que desempeña la moral en cada una. En la versión híbrida, la moral es usada para procesar un conjunto de normas expedidas institucionalmente, para hacer de ese conjunto, uno moralmente atractivo y asegurar que la moral ratifique los derechos y obligaciones institucionales. Sin embargo, esta versión genera el problema de elegir entre lo moralmente atractivo y una fidelidad hacia el pasado, lo cual resulta problemático. En la versión no-híbrida, estos problemas no se presentan porque la moralidad finalmente determina el contenido del derecho, al determinar la relevancia moral de las acciones institucionales. Desde esta perspectiva, los derechos y obligaciones jurídicas son un subconjunto de derechos y obligaciones

* Este artículo fue publicado previamente el 14 de octubre de 2003 con una revisión sustancial el 29 de abril de 2014 en la Stanford Encyclopedia of Philosophy y se publica en este número con la autorización del autor y la enciclopedia. This article was previously published by the Stanford Encyclopedia of Philosophy in October 14, 2003, with substantive revision in April 29, 2014 and is included in this issue with the permission of the author and the encyclopedia.

Artículo recibido el 10. de diciembre de 2014 y aceptado para su publicación el 11 de diciembre de 2014.

** Oxford University, nicos.stavropoulos@law.ox.ac.uk. 
NICOS STAVROPOULOS

morales genuinas, es decir, aquellas que se obtienen en virtud de la acción institucional.

\section{Palabras clave:}

Interpretativismo jurídico, Ronald Dworkin, naturaleza del derecho, contenido del derecho, obligación jurídica, obligación moral.

\section{Abstract:}

Interpretivism about law offers a philosophical explanation of the impact of institutional practice - the legally significant action and practices of political institutions - on legal rights and obligations. It says that how institutional practice affects the law is determined by certain principles, identified by interpretation, which explain why the practice should have that role. I distinguish between hybrid interpretivism, which has been extensively discussed in the literature, and a non-hybrid version that has been completely neglected. The key difference between the two lies in the role of morality in each. In the hybrid version, morality is used to process a set of institutionally conveyed norms, so as to make the set as morally attractive as possible and thereby to ensure that morality ratifies the rights and obligations that obtain under it. This operation gives rise to the problem of choosing among possible tradeoffs between moral appeal and fidelity to the past, which seems intractable. In the non-hybrid version, problems such as this do not arise. Morality ultimately determines the content of the law, by determining the moral relevance of institutional action. On this view, legal rights and obligations are a subset of genuine moral rights and obligations: those that obtain in virtue of institutional action.

\section{Keywords:}

Legal Interpretivism, Ronald Dworkin, Nature of Law, Content of Law, Legal Obligation, Moral Obligation. 
Summary: I. The Grounds of Law. II. The Orthodox View. III. Hybrid Interpretivism. IV. Pure, Nonhybrid Interpretivism. V. Why does Institutional Practice Matter? VI. Disagreement. VII. Bibliography.

Interpretivism about law offers a philosophical explanation of how institutional practice — the legally significant action and practices of political institutions - modifies legal rights and obligations. Its core claim is that the way in which institutional practice affects the law is determined by certain principles that explain why the practice should have that role. Interpretation of the practice purports to identify the principles in question and thereby the normative impact of the practice on citizens' rights and responsibilities.

Interpretivism is famously associated with Ronald Dworkin, who developed the position in a number of publications spanning 45 years (see the works of Dworkin cited in the Bibliography). Dworkin's writings have stimulated a great deal of debate (the following are some examples from the vast secondary literature: Mitchell 1983; Cohen 1984; Hart 1994 (Postscript); Raz 1972, 1986, 1994: Chapters 10 and 13, 2001; Finnis 1992; Coleman 2001 (Hart's Poscript); Brink 2001; Burley 2004; Hershovitz 2006; Ripstein 2007; Gardner 2012). We shall focus on the explanation of the position developed and defended by Dworkin (though not necessarily on his way of presenting and defending it).

\section{THE GROUNDS OF LAW}

Interpretivism is a thesis about the fundamental or constitutive explanation of legal rights and obligations (powers, privileges, and related notions) or, for short, about the grounds of law. In the relevant sense, some fact grounds another when the latter obtains in virtue of the former; and the relation between the two facts is explanatory in a non-causal, metaphysical sense of constitutive determination. ${ }^{1}$ Consider the fact that, if you buy a mobile phone at a

1 See Kit Fine, 'A Guide to Ground' in F Correia and B Schneider (eds), Metaphysical Grounding (Cambridge University Press 2012). 
store in London and it turns out to be faulty, you have a right, which is enforceable through the courts, to have it replaced or repaired by the seller. In virtue of what does the right obtain? What makes it the case, more abstractly, that any legal right or obligation obtains? What makes the proposition that some right or obligation exists true, if it is true? ${ }^{2}$ What sorts of nonlegal facts do legal rights and obligations depend upon in this fundamental way, and what is the character of the relation of dependence that holds between legal rights and obligations and the nonlegal facts in virtue of which they obtain? What is the order, in which the relevant factors appear within the fundamental explanation?

The fundamental explanation of any such right or obligation would plausibly give a role to institutional practice, the actions or practices of political institutions (in the case of your consumer right, these would notably include the action of certain institutions in Brussels, Strasbourg, and London) or other nonmoral social facts, understood in terms of the action and psychology of certain agents in which they ultimately consist. Legal positivism is committed to the view that the grounds of legal rights and obligations are limited to considerations of this kind. Interpretivism is a kind of natural law or "nonpositivist" theory since it claims that, in addition to institutional practice, certain moral facts necessarily play some role in the explanation. It makes a number of related distinctive claims within that approach.

First, interpretivism says that the explanation of rights and obligations in which both moral principles and institutional practice play some role is a kind of interpretation. Interpretation in the relevant sense is the study of normatively significant objects or of the actions of producing such objects and the practices within such production takes place. It is a familiar point from literary and other kinds of interpretation in the arts that an interpretation may impute to its object a certain content that consists in or reflects its normative significance or impact, without thereby imputing the content to the psychology of the agent who produced the object, and the interpretation's success does not depend on such implicit endorsement. In the case of law, an interpretation so understood may correctly

2 Ronald Dworkin, Law's Empire (Harvard University Press 1986). 
identify, say, some change in rights and obligations that obtained in virtue of an enactment, even though the enactment's having that impact was not considered and endorsed, in some specified sense, by the enacting institution.

Second, interpretivism says that interpretation identifies some moral principles which justify, in some specified sense, the enactment's having the impact in question. The point generalizes. For institutional practice as a whole, or any individual action or other aspect of the practice, certain moral principles justify its having the impact on the law that it does have. The principles thereby make it the case that it has it.

Third, for interpretivism, the justifying role of principles is fundamental: for any legal right or obligation, some moral principles ultimately explain how it is that institutional and other nonmoral considerations have roles as determinants of the right or obligation. In the order of explanation, morality comes first.

The relevant notion of justification has two aspects. First, the principles and therefore the moral facts that they reflect give reasons why any aspect of institutional practice or other nonmoral consideration bears on rights and obligations - why it is legally relevant. Second, they thereby determine how it does so. An interpretivist might say that certain principles of fairness or procedural justice give enactments some role in determining rights and obligations. The precise role depends on the precise reasons why enactments should have it. An appeal to principles of fair notice might give, other things equal, a central role to the plain meaning of the text of enactments. But on the hypothesis that democratically constituted assemblies have justified power to shape rights and obligations as they choose, some conception of such assemblies' linguistic intentions, or of their intention to affect the law in some particular way by the enactment, might be given priority. There may be special cases. An interpretivist might say that, because fair notice is essential to the permissibility of criminal punishment, criminal statutes affect the law only as narrowly construed. An interpretivist might further say that, in all cases, certain more specific moral principles control "the operation and effect" of all laws (as the Riggs v. Palmer court famously said, 115 NY 506 (1889)). 
Similar hypotheses would be germane to cases or institutional practice in general. For example that, because government ought to treat morally like alike when it exercises its coercive power, judicial decisions should stand; such that past decisions partly determine what rights and duties now obtain in circumstances similar in their morally relevant respects to those of precedent cases. Or, more abstractly, that, because government has a duty to bring its action under a coherent scheme of principle when it recognizes end enforces claims against some person, its institutional practice affects rights and obligations as certain principles dictate, namely the principles which together justify the institutional practice's having that role. In these examples, the moral facts that the principles express explain why and how the institutional action in question affects legal rights and duties and therefore their role is to assign to institutional practice, or any of its aspects, their own role in the explanation.

Fourth, since in these explanations the mechanism, through which institutional practice determines rights and obligations, follows from some moral principles that give the practice that very role, the rights and obligations so determined have genuine moral force. For other conceptions of law, the question of the moral force of rights and obligations in law is separate from and must come after the question of how institutional practice constitutes them. ${ }^{3}$ We first ask how the practice determines rights and obligations, which is a conceptual or otherwise nonmoral question that aims to identify the legally relevant aspects of institutional practice. Since our investigation is nonmoral, these must be understood as the factors that determine the content of legal rights and obligations, though not their force. We then ask the moral question, left open by the initial investigation, whether rights and obligations so determined truly bind. (Typically, the question takes the form of whether we have an obligation to obey the law.) The appropriate moral question is therefore severely constrained by the answer to the first, nonmoral one. We should ask what would have to be true if the institutional factors already identified as legally relevant were to constitute genuine moral rights and

3 Nicos Stavropoulos, 'Obligations and the Legal Point of View' in Andrei Marmor (ed), The Routledge Companion to Philosophy of Law (Routledge 2012). 
obligations. And of course there is no guarantee that what would have to be true would be true as often as one might suppose, or that it could be true at all. Perhaps legal rights and obligations are rarely or never morally ratified.

This approach separates the metaphysical investigation of grounds from the moral investigation of force. Considered from this perspective, a moral explanation of how institutional practice determines rights and obligations such as that offered by interpretivism may seem to belong in the second part of a complete account of the phenomenon of law, the part that concerns whether legal rights and obligations, nonmorally identified, have genuine moral force.

However, interpretivism is a thesis about the grounds of legal obligation, which purports to compete with the two-stage and other such theses, not a thesis merely about the force of the obligations that institutional practice constitutes in some nonmoral way. Rather, interpretivism builds moral investigation into the metaphysical one. The moral explanation that it offers assumes no nonmoral prior account of grounds and leaves no residual question about whether legal obligations have moral force.

That said, there is an important distinction between two ways of understanding the interpretivist claim that institutional practice and moral facts both play roles in the explanation of legal rights and obligations.

On the first way of understanding the claim, institutional practice constitutes by itself part of the law; moral facts constitute by themselves another part; and the final content of the law is some function of the two parts. On the second, institutional practice is one factor in the explanation but does not constitute any part of the law. Rather, morality and institutional practice both figure in the constitutive explanation of the law in the sense that the practice determines the content of the law as certain moral facts dictate and in virtue of those facts.

As we will see, a different version of interpretivism corresponds to each way of reading the claim that institutional practice and morality together ground legal rights and obligations. The first version, hybrid interpretivism, which understands institutional practice as an independent ground, may give rise to a concern of moral bias in the 
approach to the metaphysical problem. For it is reasonable to suspect that this kind of interpretivist sets out with the interpretative goal of finding moral force in the law, and the purpose of combining the institutional base with a moral overlay is to secure such force. On the second version, pure or nonhybrid interpretivism, which reflects the second reading of the distinction, there is no scope for such bias. For according to that version morality mandates the constitutive role that the theory assigns to institutional practice, while there is no nonmorally predefined route through which the practice is supposed to determine any obligations.

It will help to develop these claims in comparison to the orthodox view about how institutional practice affects legal obligations.

\section{THE ORTHODOX VIEW}

On the orthodox view, ${ }^{4}$ questions about the existence and content of legal rights and obligations are questions purely of institutional history. Legal rights and obligations are creatures of institutional action. Institutions that count as authoritative in a legal system create, modify, or extinguish a legal right or obligation, primarily through the production of a legal text such as a statute, decree, regulation, or judicial decision that sets it out or logically entails it. The production of a legal text is an act of communication that has its own logic. In producing such a text, an institution is to be understood as issuing a directive addressed to certain subjects and meant to direct the subjects' action. The directive conveys a norm or, more precisely, conveys the institution's intention to create, by the act of conveying the intention, a norm (a standard that permits or mandates some action) with the same content. When an institution issues a directive, subjects are meant to take the stipulated action because the institution said so. From the perspective of the institution that issued it, a directive always has the force of a binding order that subjects are meant to obey and brings into existence a norm, namely that sub-

4 Reflected in HLA Hart, The Concept of Law (2nd edn, Clarendon Press 1994) and developed in its strongest form in Joseph Raz, Ethics in the Public Domain (Clarendon Press 1994). 
jects ought to take the action the institution said they should take. The norms produced by institutional communication so understood (and possibly also the norms that institutions consider and tacitly endorse in their customary practices) are valid norms of the system and make up the entire content of the law. A legal right or obligation exists when and in virtue of the fact that a norm that is part of the law so understood confers or imposes it, therefore ultimately in virtue of the fact that some institution said so. On the orthodox view, it is a basic, conceptual truth about law that institutional action determines legal rights and obligations in this way.

These considerations describe the mechanism through which authoritative institutional action constitutes obligations. Further questions arise. What makes for authoritativeness in the relevant sense (which institutions count as authoritative in the system)? How is legal validity related to moral force?

Taking them in the order of explanation from authoritative action to obligation, the question which institutions count as authoritative in the system is to be settled in part by other norms constituted by authoritative directive, which count as more fundamental, and must be settled ultimately by some further aspects of institutional practice, e.g., the settled official practice of recognition of the action of agents or institutions as a source of norms (a practice that may be considered itself as constituting a norm that regulates the action of officials and is tacitly endorsed in official practice. ${ }^{5}$ On the other hand, the considerations in discussion settle the legal relevance of institutional decisions: the decisions matter to the law as institutionally valid norms that impose obligations, which are genuine moral obligations from the point of view of the system. ${ }^{6}$ They settle, at the same time, the terms in which the further question of the decisions' genuine normative relevance must be posed. This becomes the question whether the directives work as advertised, such that they truly create norms (norms that are valid simpliciter, not merely

5 See Hart (n 4).

6 Joseph Raz, Practical Reason and Norms (2nd edn with Postscript, Princeton University Press 1990, originally published London: Hutchinson, 1975) contra HLA Hart, Essays on Bentham (Clarendon Press 1982). 
NICOS STAVROPOULOS

institutionally) and therefore whether subjects do acquire an obligation to take some action because the relevant institution said so. In sum, the question of genuine normative relevance of institutional action becomes the question of whether the institutions have legitimate authority so understood. ${ }^{7}$ Finally, these considerations leave open the question of what moral conditions must be met for the institutions to have legitimate authority, which is the business of theories of justification of authority, such as theories that appeal to consent, political association, democracy, or the ability of legal authority to secure cooperation or help subjects better conform to right reason. ${ }^{8}$ Notice that on Dworkin's view political obligation is grounded in political association. Association generates obligations that associates owe each other, rather than an obligation to obey authoritative directives.

Some writers defend a less austere version of this model, by weakening the notion of validity. They say that the validity of an institutionally produced norm needn't depend solely on whether an institution has issued a directive with the corresponding content but may further depend on certain moral conditions, if such conditions are laid down by more fundamental norms. For example, if the Constitution entrenches some values, the conditions of validity of ordinary legislation would include those values. In such a case, the values would play the crucial role only because some institution -a constitutional assembly - said so. In another variant, values may be made relevant to legal validity by the customary norm that governs judicial practice, which is the most fundamental norm, constitutive of a legal system, on the classic model that Hart made famous. In that case, the nonnormative social fact of custom that constitutes the fundamental norm would make the values relevant to the validity of ordinary norms. ${ }^{9}$ In all these cases, rights and obligations in law are

7 Raz (n 6).

8 For an overview, see Tom Christiano, 'Authority', The Stanford Encyclopedia of Philosophy (Spring 2013 Edition) Edward N Zalta (ed) < http://plato.stanford.edu/ entries/authority/>. See further John Finnis, Natural Law and Natural Rights (Oxford University Press 1980); Joseph Raz, 'Dworkin: a New Link in the Chain' (1986) 74 California Law Review 1103; Dworkin (n 2).

9 Jules Coleman, The Practice of Principle (Oxford University Press 2001). 
explained ultimately by nonnormative social facts, but moral facts occupy some place further up in the order of explanation.

\section{HYBRID INTERPRETIVISM}

Hybrid interpretivism represents another possibility along that spectrum. It begins at the austere norm-based explanation of law but defends an even more inclusive conception.

For hybrid interpretivism, the set of institutionally valid norms - the norms determined by what the institutions said- forms the interpretive baseline. Interpretation is a kind of moral processing of these norms. To interpret is to assess the norms constituted by institutional communication and adjust the set in order to make it more attractive in some way - to make it better conform to the abstract point of legal practice against which it is interpreted. Hybrid interpretivism is therefore the thesis that the institutional input to the interpretive process - what the institutions said- does not alone yield the final, complete set of legally valid norms. Rather, the final set of valid norms is the output of the process. The final set takes as an additional input certain moral facts. Yet the contribution of each kind of input remains distinct. Each episode of institutional communication, by itself, creates an institutionally valid norm which it makes available for interpretive scrutiny. The hybrid interpretivist considers as settled, without reference to any moral or other substantive normative facts, how the contingencies of institutional practice contribute to the law: he relies on the orthodox explanation of that mechanism. ${ }^{10}$ But he thinks that there are additional conditions of validity. Substantive normative facts may filter, supplement, or otherwise modify the original norms, as dictated by the interpretative goals in play. Legal validity of a norm now entails that the norm was either created by official communication and survived interpretive scrutiny or that it bears a certain relation, defined by the general point of legal practice, to such survivor norms.

A variant of hybrid interpretivism is the conception of law as consisting of both rules and principles. This is typically attributed to

10 Cf Raz (n 8), attributing the hybrid view to Dworkin. 
Dworkin's early work. ${ }^{11}$ Institutions convey rules, as Hart claimed. These are screened and rejected or modified to the extent that they conflict with certain basic moral principles of fairness or justice, as they did in Riggs. Rules are also supplemented with non-conflicting principles in hard cases, where the rules alone yield no determinate results. In such cases, the principles fill the gaps. The law is the hybrid of the two sets of standards generated by the filtering and gapfilling operation.

A sophisticated variant of this view can be built around the notion of principled consistency ("integrity") which, according to Dworkin's later work, is a distinct political virtue that forms the foundation of law. ${ }^{12}$ Taking principled consistency in the law as an interpretative target, the interpreter identifies a set of principles that together justify the given set of norms. The interpreter works therefore with two sets of norms, one composed of norms conveyed by institutions, the other composed of uncreated, genuine moral norms - general moral principles. He is to compare the two sets, and adjust the first in light of the second. He may then say that the law now includes both the original norms and the principles (or perhaps some further norms determined by the principles). Like its older, rules-and-principles cousin, the law is a hybrid, a creature of the two separate sets of standards, one grounded in social facts, the other in moral facts, that interpretation blends together. ${ }^{13}$

In this operation, the principles (and the further norms that they determine) are valid in virtue of the relation of justification they bear to the original norms. In the presently relevant sense of justification, an eligible principle is one that reflects an ideal arrangement, prescinding from institutional practice, against which norms that the practice produced are measured, provided the principle is at least logically consistent with the norms. Consider principles that set out the morally right way to identify and deal with private wrongs, regardless of the actual practice of institutions in that area. Such prin-

11 Ronald Dworkin, Taking Rights Seriously (Duckworth 1978); notice that Dworkin actually disowns this view: 1978, at 76.

12 Dworkin (n 2).

13 Cf. Raz (n 8). 
ciples would be germane to the project of designing institutions of tort from scratch or of reforming existing ones. But for some principles to be said to justify some actual, institutionally created, norms of tort, as the hybrid interpretivist says his favoured principles do, it wouldn't be enough that the principles captured the relevant ideals. They would further need to be at least consistent, in some specified sense, with the norms. A principle wouldn't count as justifying an institutionally created norm in any sense, when it prohibited what the norm required or permitted. In the conception in discussion, for a putative set of principles, consistency, in some specified sense, with the set of the original norms is a condition of eligibility additional to and independent of merit.

The understanding of principled consistency used in this conception of interpretivism corresponds to one understanding of Dworkin's famous distinction between fit and justification, as dimensions of interpretation. ${ }^{14}$ Dworkin said that correct interpretation must both fit and justify its object. On the understanding in discussion, fit operates as a threshold constraint on eligibility of interpretations. Independent moral appeal governs the choice among alternatives that pass the threshold. ${ }^{15}$ Fit, on this conception, is meant to ensure that a candidate interpretation is indeed an interpretation of some object rather than an invention. It is a nonmoral constraint, in two ways. First, it is meant to secure consistency with a set of norms that are grounded in nonmoral considerations -in the action and psychology of agents and institutions. Second, the relevant notion of consistency itself is meant to be nonmoral, a constraint of formal consistency between norms and principles. ${ }^{16}$ The thought is that the original set of norms could not really constrain interpretation if substantive, moral considerations played some role in determining what it is to fit the norms. If the notion of fit were tainted by

14 Dworkin (n 2).

15 Cf. Raz (n 4) 223.

16 Cf. Greenberg on fit as a matter of formal consistency with practice. Greenberg argues that a constraint of formal consistency is empty. Mark Greenberg, 'How Facts Make Law' (2004) 10 Legal Theory 157-98. Available online <http://papers. ssrn.com/sol3/papers.cfm?abstract_id=797125>. 
the very kind of consideration that defines the ideals against which the actual norms are to be measured, the distinction between interpreting the actual practice of institutions and inventing a new, better practice would be erased.

In order to pursue principled consistency in the law while taking the set of institutionally created norms as the baseline, the interpreter will have to take his objective as composite, which can be analysed into its components. He has to strive for principle and for consistency.

Some of the time, he may be able to pursue both objectives simultaneously without difficulty. Given some principles that justify norms in this sense, the interpreter might add to the set certain further norms such as those implied by the explicit communication that constitutes the original norms, if doing so would give better effect to the principles and thereby improve principled consistency (on the current understanding of that notion) in the way government treats its citizens. Or he may add certain norms that correspond to the relevant principles so do not conflict with the prior, institutionally communicated norms with which by hypothesis the principles are consistent, regardless of whether the new norms are implied by the prior norms; or (if this is different) he may add the norms that judges are morally required to rely on in order to resolve residual matters in domains that are only partially regulated by the original set. In his view, the expanded rather than the original set of standards would be valid law.

But the interpreter can't reasonably hope that his work will always be so easy. Even assuming a fairly decent institutional history, the set of norms that would form the baseline would be the product of political action taken by different agents at different times, with a variety of motives and facing different political and other constraints in their choices. ${ }^{17}$ The norms produced might conflict in their justification, some consistent with one scheme but indefensible under another. There might be no scheme of independently appealing principles - certainly not a perfectly just and otherwise compelling scheme- consistent with all the norms without exception. If the

17 Raz (n 4). 


\section{LEGAL INTERPRETIVISM}

baseline included a norm that couldn't be justified by his favored scheme of principle, the interpreter might have to try a different, less than perfect scheme, under which the problematic norm might be subsumed, and trade merit for consistency. But even if he were willing to accept a measure of imperfection in a scheme's appeal, he might fail to find any eligible scheme, in which case he would have to reject the norm. Of course, if the communicated norms were to function as a fundamental, pre-interpretive constraint, rejection would have to be rare and subject to special justification. Only something about the remaining institutional norms - that they all cohered with a given set of principles - could allow the interpreter to reject the outlier.

On the other hand, there might be several mutually inconsistent schemes of principle, each consistent with the original set of norms. The interpreter would therefore have to choose from among these schemes on grounds other than consistency with institutional practice. Normally it would not be permissible, on this model, to add a principle to the original set of norms (or to rely upon it to generate more norms) just because it was attractive. Rather, the principle would have to bear a relation at least of consistency with some norm in the original set. But, in case that relation did not uniquely determine the principles in a scheme, the interpreter would have to choose without being able to ground the choice by appeal to the original set. He would have to choose on merit alone. ${ }^{18}$

A harder problem would arise where there are multiple candidate schemes of principle that are unequal in both independent appeal and consistency, and imperfect in each dimension. Should the interpreter reject more norms in return for an improvement in appeal, or accept a larger compromise in appeal for a gain in consistency? At

18 This is a consequence of the model that has attracted a lot of criticism. See Raz (n 4) 223-6; John Finnis, 'On Reason and Authority in Law's Empire' (1987), 6 Law and Philosophy 357; John Finnis, 'Natural Law and Legal Reasoning', in R George (ed), Natural Law Theory (Clarendon Press 1992). For Dworkin's protests that the distinction is merely heuristic, and should not be understood to mark two different dimensions of interpretation, see Ronald Dworkin, 'Natural Law Revisited' (1982) 34 University of Florida Law Review 165; Dworkin (n 2) and Ronald Dworkin, Justice in Robes (Harvard University Press 2006). 
NICOS STAVROPOULOS

least in some cases, where the relative gains and losses would not be disproportionate on some conception of their magnitude, the interpreter could not appeal to either merit or consistency to justify a choice and it is unclear to what else he might appeal.

There are further difficulties. Hybrid interpretivism gives us no reason to abandon a sharp distinction between the pre-interpretively given corpus of institutionally valid norms constituted by communication alone, on which interpretation operates, and the final set of norms that interpretation yields. It therefore makes it seem that the question whether the law is limited to the unprocessed input or includes the processed output is merely verbal. ${ }^{19}$

Given these problems, hybrid interpretivism makes interpretation too close to cooking the books to make them reflect some ideal which, left alone, they fail. It is reasonable to take it, not as a doctrine about what determines the content of the law, but instead as an argument about how best to decide hard cases given the law (now understood to be restricted to the institutionally communicated norms). It becomes a theory of adjudication, which builds upon the orthodox explanation of how institutional action creates rights and obligations by way of conveying norms, and recommends some way of resolving disputes given those norms. Even so reinterpreted, problems remain. For hybrid interpretivism now seems to recommend that judges extend the effect of any norms they find (or at least the ones not bad enough to fail the test of consistency with even the least acceptable scheme of principle) into situations the norms don't explicitly or clearly regulate, and it's doubtful that some political ideal should support this conservative policy. ${ }^{20}$

The immediate source of the difficulties lies in the composite character of the ideal of principled consistency deployed by hybrid interpretivism, which entails that the interpreter must simultaneously aim at consistency and merit, understood as separate targets

19 Hart (n 4); Frederick Schauer, 'Positivism as Pariah', in RP George (ed), The Autonomy of Law: Essays on Legal Positivism (Clarendon Press 1996) 31-55; Mark Greenberg, 'The Standard Picture and Its Discontents' in Leslie Green and Brian Leiter (eds), Oxford Studies in Philosophy of Law, vol 1 (Oxford University Press 2011).

20 Raz (n 8) 1111; Raz (n 4) 224. 
which needn't coincide. Given the difficulties, it is unclear that interpretation could secure completeness, understood as power to resolve all possible disputes. ${ }^{21}$ The composite conception of principled consistency is forced upon the hybrid interpretivist by his fundamental commitment, to which the difficulties are ultimately traced: that the starting point of interpretation must be some norms constituted by the contingencies of institutional communication, and that interpretation's purpose is to compare and somehow to reconcile those norms with ideals.

The hybrid interpretivist may claim that it is a deep constitutive fact about law that the institutional input to the law must be interpreted in the relevant sense. Still, his view is hybrid in that it takes as the fundamental, pre-interpretive constituent of the law some norm-creating directives. So the basic explanation of the legal relevance of political decisions - that the decisions matter to legal rights and obligations and indeed that they matter as such directives - is not itself interpretive in character. The fact that, other things equal, an institution's say-so makes law, is a primitive legal fact, or at least a legal fact that is not to be explained by either the nature of interpretation or by a substantive interpretive conclusion in the legal domain. Hybrid interpretivism is not therefore faithful to the basic interpretivist idea that the legal relevance of institutional practice is fundamentally explained by some political ideals. For example, that the duty of government to treat its citizens in a manner consistent in principle makes institutional decisions relevant to their legal obligations, rather than supplement the decisions or filter their results.

Before we turn to that alternative, it is worth noting that hybrid interpretivism differs from the view, not similarly unfaithful to the basic interpretivist idea, that some political ideal (perhaps involving fair notice) makes it the case that institutional decisions matter to the law as norms whose content is identical to the content of insti-

21 Which is often understood to be interpretation's further, perhaps basic objective; see Raz (n 4); Finnis (n 18); see also Brian Leiter, Naturalizing Jurisprudence: Essays on American Legal Realism and Naturalism in Legal Philosophy (Oxford University Press 2007), who claims that the thesis that there is a right answer to all legal questions is at the core of Dworkin's project). 
tutional communication. (An example is the doctrine Dworkin calls "conventionalism", an interpretive conception of law that he rejects as inferior to the conception he calls "integrity".) For such a view, political ideals and institutional history would together constitute the content of the law in the right way. As a result, interpretation would be over at the stage of identification of the norms. Hybrid interpretivism, by contrast, takes the norms as the object of interpretation and so its starting point, not its end.

\section{PuRe, Nonhybrid InTERPRETIVISM}

Pure interpretivism is nonhybrid. It understands principles, institutional practice, and their relation differently.

Interpretivism begins at the question how institutional practice bears on rights and obligations. For hybrid interpretivism, this question is, at least in part, pre-empted by the orthodox view on which it builds. According to the orthodox view, the practice itself (and ultimately the very idea of law as that is commonly understood $)^{22}$ determines how it bears on rights and obligations. This is so because the practice consists in communication or tacit endorsement of norms meant to place subjects under obligations by virtue of communicating or endorsing the norms. By taking all this as given, hybrid interpretivism therefore begs in some considerable part the fundamental question at which interpretivism says one must begin.

By doing so, hybrid interpretivism commits itself to the existence of some normative content - the norms and the obligations that follow from them - that is constituted by institutional practice alone. Moral principles contribute some more normative content, and the final content imputed to the law is some combination of the two.

By shedding the orthodox base layer of its hybrid counterpart, pure, nonhybrid interpretivism takes no part of the basic question as settled in that way. It therefore does not take the practice already to contribute norms, obligations, or any other kind of normative content, whether outright or from a point of view, or to consist in communication that conveys or is intended to constitute normative 
content. It understands the idea that the practice, nonnormatively specified, plays a role in the fundamental explanation of the content of the law differently: the practice is a factor in the explanation, but does not alone constitute any content. It says that moral principles determine how the practice may determine such content.

There are several important implications. Institutional practice is conceived in terms of actions and attitudes, not norms or texts and utterances that convey norms. Assemblies introduce, debate, amend, and enact statutes. Agencies produce and adopt regulations. Courts consider disputes, resolve them and issue opinions, including dissents, which offer reasons that support resolving the disputes in one or another way. In short, institutions and agents operating within them take actions, including the action of producing certain texts or utterances, and hold a variety of attitudes, whose role as determinants of legal rights and obligations is itself determined by the moral principles in play. The principles for example may assign a certain legal significance to the fact that some assembly produced a text with some content, rather than to a norm with that content, allegedly constituted by the assembly's action. Institutional practice is not therefore assumed to be a set of directives or other kind of communication of the rights and obligations that obtain as a result of the practice, with its own logic that is logic of the law, a particular way in which enactments or decisions "are meant" to constitute obligations. How institutional action constitutes obligations (the metaphysical mechanism) a matter for theory. There is no special, privileged institutional perspective so no internal, perspectival notion of obligation.

A further implication is that legal obligation is not constituted by the say-so of institutions, nor is its content determined by what institutions said. Legal obligation need not match the content of official language (though morality will often see to it that it does) and needn't be to take action for the reason that some institution said so. If that's obedience, legal obligation needn't be obligation to obey.

It follows that the purpose of moral explanation is not to ratify obligations whose content (and perspectival existence) is given in advance of the explanation. It is to explain how obligations come to obtain, and therefore what their content is. No prior question of content is taken as settled, and no further question of force is left open. 
NICOS STAVROPOULOS

Since it rejects the orthodox view that institutions communicate (or tacitly endorse) valid legal norms, pure interpretivism has no use for the orthodox notion of norms understood to play substantial explanatory roles (or for a metaphysically important notion of a law, as distinct from the informal notion that picks out statutes or other legislation) and is not a doctrine about conditions of validity. Legal norms (or rules or other standards) may figure in conclusions of reasoning that summarize the legal effect of institutional practice and are useful for exposition. Since standards so understood are derived from the explanation of the legal effect of practice, their existence is not constitutively responsible for the effect. They may also play an epistemic role: we may draw inferences about what rights and obligations exist from tried and tested formulations of standards, but the inferences are always subject to independent confirmation and the formulations are subject to revision. ${ }^{23}$

A related point concerns the structure of the explanation. On the orthodox explanation of law, institutions issue directives. The impact of each individual institutional action is therefore distinct: it is the addition of some valid norm to the law. Norms so constituted are then weaved together to form the complete content of the law. (This is not to deny that some of the norms may concern precisely how to weave norms together, for example by stipulating that lex posterior derogat legi priori.) The explanation is in that sense atomistic. ${ }^{24}$ Nonhybrid interpretivism is not so committed. Since it holds that morality determines how institutional practice affects rights and obligations, it inherits the holistic structure of morality: the whole of morality confronts the whole of institutional practice and determines its effect, which interpretation purports to identify. Particular episodes in institutional practice, say the enactment of a new statute, change rights and obligations by changing the content of the practice and therefore its moral effect. ${ }^{25}$

23 Dworkin (n 11) 76; Mark Greenberg, 'The Prism of Rules' (2007) UCLA School of Law Research Paper No. 07-31, available online at <http://papers.ssrn. com/sol3/papers.cfm?abstract_id=1042121>; Nicos Stavropoulos, 'Words and Obligations' in Andrea Dolcetti, Luis Duarte d'Almeida and James Edwards (eds), Reading HLA Hart's 'The Concept of Law' (Hart Publishing 2013).

24 Greenberg (n 23).

25 Idem; Greenberg (n 19). 
The notion of justification is very different on this view. Moral facts fix the relevance of other factors. The moral principles that reflect those facts do not add content to the law, to be combined with content otherwise contributed by institutions. The moral facts are therefore the grounds of law, but do not directly determine its content. They determine how institutional practice determines the law, i. e., which precise aspect of the practice is relevant to the practice's contribution to the law.

A familiar hypothesis of that kind involves the principle that disputes that are like in morally relevant respects should be treated alike. This hypothesis dictates identifying morally relevant respects in cases, which introduces a role for further hypotheses involving more specific principles that pick out those respects. Consider an imaginary case, Roe v Doe, where Doe is ordered to compensate Roe for the damage that she incurred, which was caused by his action. In the currently relevant sense, a principle, e.g., that one is responsible for damage caused by one's carelessness, on some conception of due care, would be germane in case it identified the factor that was relevant to Doe's liability. If it did, it would normatively explain why Doe was ordered to pay - it would show how it's right that he was. At the same time, the principle would determine how this decision would bear on other cases, given the duty to treat like alike. It would reflect the facts that ground the duty of due care and the liability that due care entails that is articulated by the principle. A principle that figures in such a hypothesis must, first, justify resolving an actual or hypothetical contested case in a particular way; and, second, justify resolving past actual or hypothetical settled cases, i.e., cases the outcome of which is not in dispute in the instant case, in the way they were or would have been resolved. Hypotheses of this character have similar functions, whether they concern the action of institutions or of litigants. By picking out the morally relevant features of some aspect of institutional practice, hypotheses of principle function as explanations of the legal relevance of that aspect of the practice today.

Candidate factors are not restricted to what institutions said; nor are they restricted to what settled legal opinion considers relevant. Perhaps the court said that the fact that the damage was caused by 
NICOS STAVROPOULOS

Doe's carelessness was what made it the case that he had to pay. But the court might not have said so - it might have mentioned something else, or said some conflicting things. Or it might have mentioned carelessness and damage, but failed to say whether the magnitude and likelihood of the damage compared to the burden of precaution were germane to the standard of care that Doe failed. Would the fact that the court failed to mention these considerations rule out their relevance to future cases? The answer would depend on some further principles that explained why and how past decisions as a kind are relevant, if they are, to instant cases. If courts should respect their past decisions because doing so reduces uncertainty and other costs of economic transactions, a principle that the court failed to articulate might be irrelevant to the bearing of a case on future cases. But if courts' responsibility is to engage with their past decisions because they must act with integrity, such principles may be decisive. ${ }^{26}$

These complications are not special to case law. A number of candidate factors might plausibly determine a statute's effect on legal obligations. The plain meaning of the text of the statute; the actual (linguistic) intentions of certain members or the assembly as a whole (on some specification of corporate linguistic intention) to say or state something by producing the text; their intentions to change legal rights and obligations in a certain way, i.e., to secure some legal effect by using the specific language of the statute; the effect they would have intended to achieve if they had considered some circumstances they did not; the effect they wanted the statute to be regarded by the courts to have; the effect they expected it to be regarded to have; their second-order intention that a certain firstorder intention, e.g., their linguistic intention, control the effect of the statute; the political practices that existed before the relevant statute was enacted and were not thought at the time and ever since to have been affected by its enactment; ${ }^{27}$ the purposes the statute

${ }^{26}$ Scott Hershovitz (ed), 'Integrity and Stare Decisis' in Exploring Law's Empire (Oxford University Press 2006).

27 Antonin Scalia, A Matter of Interpretation: Federal Courts and the Law (with commentary edited by Amy Gutmann, Princeton University Press 1998). 
was formally announced to serve in its preamble or in its sponsors' reports; the reasons given in its defense during debates; and so on. Often all of these considerations will pull in the same direction, so the choice among them would make no perceptible difference. But they needn't, and we can always construct hypotheticals to test their relative contribution to the impact that some decision has on the law.

For pure interpretivism, interpretive hypotheses are such tests and are designed to support the relevant theoretical choices. The hypotheses appeal to principles of political morality that justify some particular aspect of the institutions' action having a role as a determinant of rights and obligation. By doing so, they aim to establish, for each candidate determinant of law, its precise impact on the law, including its impact when some other candidate pulls in a different direction. ${ }^{28}$

Candidate relevant factors include considerations - texts, practices, or attitudes - that concern the very question how candidate determinants bear on the law. Intentions about which intentions count, mentioned above ${ }^{29}$ are such factors and canons or conventions of interpretation and procedural provisions are familiar further examples. These are not exempt from the question why and so how they should bear on the law. Something other than the factors must determine their relevance to the law, even when it is pre-theoretically plausible that they are indeed relevant. For example, an interpretive convention tends to have a significant effect on expectations about how the relevance of the other institutional factors that the convention concerns would be assessed in court, such that considerations of fairness favour conforming to the convention. If so, the convention is vindicated by considerations other than itself, and this holds for any similar factor. ${ }^{30}$

28 Cf Ronald Dworkin, A Matter of Principle (Harvard University Press 1985); Dworkin (n 2); Ronald Dworkin, 'Comment' in Antonin Scalia (ed), A Matter of Interpretation: Federal Courts and the Law (with commentary edited by Amy Gutmann, Princeton University Press 1998); Greenberg (n 16); Stavropoulos (n 23).

29 Discussed in Dworkin (n 28) and (n 2).

30 See Dworkin (n 28) and (n 2) regarding legislative intentions; Greenberg (n 16) regarding any aspect of the practice that concerns the relevance of other aspects. 
In this conception, the difficulties of hybrid interpretivism do not arise. Principles have the role of identifying the legally relevant aspects of institutional practice. Principled consistency in this conception therefore consists in consistency in the morally relevant respects of the practice. Principled consistency so understood has no room for prior or residual concern about fidelity to the practice. The pure interpretivist would say that, since it is not the case that we compare moral ideals with some nonmoral code of norms constituted by the content of institutional communication, the question does not arise whether we ought to trade merit for consistency, to weaken our morality to make it compatible with our history. Or whether we should treat some ideal as a ground of obligation just because our institutions have not clearly said anything inconsistent with it. Since we ask in what ways institutional history is morally relevant, the correct answer is determined by moral fact, not a moral approximation or an ideal diluted by history. Yet the answer does not describe ideal arrangements - those we should want to have, prescinding from institutional history - but the normative significance of the arrangements we do have. So we shouldn't worry about our morality being too perfect for our history, or not as perfect as our history might let us get away with, or about how to choose between the two. We deploy morality, as is, not to compare it with history but to find what difference history made.

\section{Why does Institutional Practice Matter?}

We have been discussing the question which aspect of institutional practice is relevant to legal rights and obligations. But how is it that some or other aspect of institutional practice is so relevant? The pure interpretivist case would be severely undercut if at that abstract level morality played no role in the explanation of relevance.

Pure interpretivism offers a thoroughly moral explanation of the normative relevance of institutional practice, by identifying a moral concern that gives the practice such relevance. It characteristically begins at some familiar, structural features of legal practice, whose existence is usually tacitly assumed. The first concerns the institutional 


\section{LEGAL INTERPRETIVISM}

character of law. It's an unspoken fundamental assumption in law that claims of legal right or obligation are claims grounded, in some appropriate way, in past institutional decisions and standing practices of government -in actual not ideal institutional arrangements - and that only claims so grounded shall be recognized and enforced. Call that kind of grounding the legality of a claim. The second concerns the role that the legality of a claim is supposed to play in relation to some moral concern. It is not merely uncharacteristic but also impermissible for legal institutions to enforce some claim against a person, unless the claim meets the conditions of legality by being appropriately grounded in institutional practice.

This is not the discredited claim that what it is for a legal obligation to take some action to exist is for some sanction to be attached to not taking the action, or that a coercive clause must of necessity be attached to every law. Rather, it is the claim that putative rights and obligations may be enforced through the institutions of government only when they bear a certain relation to the institutions' practice. This is a normative constraint that is not dependent on whether occasion for enforcement ever arises. It is closer to Kelsen's view that legality is at bottom a boundary separating permissible coercion exercised in the name of the community and impermissible coercion not so exercised. ${ }^{31}$

A familiar hypothesis is that the moral concern in play is raised by institutions' effective power to use force or otherwise coercively to direct citizens' action. Legality is supposed to constrain or regulate that power, by constituting a necessary condition that demands against persons must meet if they are to be permissibly enforced. Notice that in this role, legality is not a moral filter, a moral condition of validity of norms. In the hypothesis in discussion, there is no pool of candidate norms, identified by nonmoral tests, to be put through a further, moral test, before they are pronounced finally valid. Rather, legality is a condition of permissible enforcement of demands against a person, a special moral test that applies to any

31 Though of course for Kelsen this would be a moral boundary that only need exist in the eyes of the law, whether or not it exists outright; see Hans Kelsen, Principles of International Law (Rinehart \& Co. 1952). 
such demand, including those that are entirely unfounded as well as those that may pass other moral tests. ${ }^{32}$

On this view, it is essential to law that the legality of a demand -its being grounded in institutional history in the right way- is a condition of its permissible enforcement. This is a claim that is at once metaphysical - a claim about the nature of law- and normative - a claim about the morality of coercion. It says that the correct explanation of why institutional history should have the role of constraint on coercive enforcement (a substantive normative explanation of a political ideal that makes history morally relevant to the permissible enforcement of claims) determines the correct explanation of how institutional history determines legal rights and obligations (the constitutive explanation of what it is, more precisely, for a claim of right and obligation to be grounded in institutional history in the legally appropriate way).

This general explanatory template can be filled out in a number of ways. The best known ${ }^{33}$ begins at the claim that what explains the role of institutional history in the identification and enforcement of obligation is that government's action should be consistent in principle - some version of the virtue of treating what's morally like alike, perhaps ultimately to be explained by some combination of reasons of fairness and government's special duty to treat citizens as equals.

This approach is based on the view that, emergencies aside, it is wrong for government to exercise its power to coerce if such an exercise is not allowed by law. Here, the law is meant to work as a constraint on government's action, and its role as a constraint is claimed to be valuable. (Recall that the constraint follows from moral fact, not the logic of institutional action.) If government is to stand behind my request coercively to enforce my demand against you, it must justify its action by appeal to its institutional practice. The ex-

32 This is the moral concern, and corresponding role of legality, developed in Dworkin (n 2), see also Ronald Dworkin, Justice for Hedgehogs (Harvard University Press 2011). Alternative interpretivist hypotheses might assign to legality a similarly distinctive role in relation to some other moral concern.

33 Dworkin (n 2), also (n 18) and (n 32). 
planation of the role of legality in the exercise of coercive power is that government is under a standing obligation always to act in line with an honest conception of justice. It cannot begin to meet this obligation unless it takes what it has said and done on pertinent issues as relevant to what it may do now. Justice is egalitarian in character. The familiar requirement of treating morally like alike would bind government to use force on a given occasion in the way it has used or would use it in any other actual or hypothetical circumstances relevantly similar to the instant one.

Principled consistency in the use of force does not mean, in this, nonhybrid conception, that government is bound punctiliously to apply all norms created by the directives of authorities according to their terms, or to repeat past mistakes. The claim is rather that the morality of coercive interaction makes institutional practice relevant to what may or must be done now. Government must take its other action (legislation, cases, etc.) seriously and act now in a way that's consistent in principle with that action, taken together. Any past action that cannot be justified under the scheme that justifies the rest is action that is not after all relevant to what is to be done now, and is to be set aside as mistake. We must revise our understanding of principles on which we acted in the past, which may have led us to such mistakes.

Since government must make its action consistent in principle (rather than formally), the conclusion we should derive from this normative explanation, suitably elaborated, is that certain moral principles that together justify institutional decisions and settled practice determine legal rights and obligations. These are moral rights and obligations that bear the right relation to institutional practice, which therefore government may enforce, and must do so on demand, through its institutions. ${ }^{34}$

On this view, the morality of coercion fundamentally explains the normative relevance of actual institutions. ${ }^{35}$ A related familiar hypothesis in political philosophy assigns to the morality of coercion a

34 Dworkin (n 2) and (n 32).

35 Nicos Stavropoulos, 'The Relevance of Coercion: Some Preliminaries' (2009), 22 Ratio Juris 339. 
NICOS STAVROPOULOS

fundamental role in the explanation of duties of socioeconomic justice. On this hypothesis, duties of justice (whether or not egalitarian, as many philosophers suppose) obtain in virtue of the political relation that holds among those who are placed under the coercive control of some government, and are discharged by designing institutions in a way that meets certain constraints. ${ }^{36}$ Whether or not coercion matters in that way is a topic much discussed in political philosophy, where writers are concerned with ideal arrangements. The question is underexplored in relation to law, where we are concerned with the normative effect of actual arrangements.

As indicated above, nonhybrid interpretivism is not committed as such to the appeal to egalitarian concerns related to coercive enforcement. Alternative explanations that vindicate the assumed role of institutional practice in grounding obligations might be built on the basis of considerations of fair notice ${ }^{37}$ or other key principles of political morality, perhaps including considerations related to authority.

A further question concerns boundaries. This is a matter of the first importance for the orthodox view, which purports to organize obligations by institutional source, but seems less urgent for pure interpretivism, on which no obligations are explained by institutional contingencies alone. Recall that, on the current approach, some moral concern makes institutional practice relevant to rights and obligations, and the rights and obligations in question have genuine moral force. But it doesn't follow that just any action of government that has moral consequences, or even action that changes rights and obligations, and any change in rights or obligations that obtains in consequence of such action, is to be regarded as falling within the legal domain. The interpretivist says that the justifying connection between institutional practice and legal rights and obligations must be such as to serve as an adequate response to the moral concern that is characteristic of legal practice. On the hypothesis we have been discussing, the concern is raised by coercive enforcement. A

36 Thomas Nagel, 'The Problem of Global Justice' (2005) 33 Philosophy \& Public Affairs 113.

37 Cf. the doctrine Dworkin calls “conventionalism”, Dworkin (n 2). 
conception of law must therefore articulate the relation that must hold between some right or obligation and institutional practice if the right or obligation is to be permissibly enforced. (Recall that that moral relation is, on this hypothesis, the relation of legality, and rights and duties are legal when and because they bear that relation to institutional practice). The requirement of legality so understood plausibly imposes procedural and other constraints on the kind of institutional action or other aspect of institutional practice that may ground legal rights and obligations. Officials often make public announcements about their future behavior designed to shape the expectations and thereby the action of their intended audience (as did the President of the European Central Bank when he announced, at a major investment conference organized by the British government, that the ECB will "do whatever it takes to preserve" the currency). ${ }^{38}$ Normally when we give assurances designed to raise expectations, we thereby change what we owe to those that we assure, often coming to have a duty to perform. But there is no reason to expect that action of this kind, taken by officials outside normal procedures, should in itself affect any legal right or duty — though equally there is no reason to rule out its playing some role in the determination of the impact of other, procedurally proper institutional action or other aspect of the practice.

For similar substantive reasons, it does not follow from its conception of legal rights and duties as moral consequences of institutional action, that interpretivism cannot distinguish between enforceable rights and duties that obtain in consequence of the kind of institutional action whose role as shaper of such rights and duties serves the value of legality, on the appropriate conception, on the one hand; and further moral consequences, downstream of these rights and duties, on the other. On the hypothesis in discussion, the grounding relation between rights or duties and institutional practice allays the relevant moral concern if it makes for principled consistency in the practice (in the way discussed in more detail in this

38 Mario Draghi, 'Speech', President of the European Central Bank, Global Investment Conference in London 26 July 2012. Available at <http://www.ecb.euro pa.eu/press/key/date/2012/html/sp120726.en.html>. 
Section and Section IV). On this basis, we can distinguish between the legal duty of Albert, who owns a small business, to purchase a new, more costly health insurance program for his employees following the enactment of some new health care legislation that specifies a certain minimum coverage, and his further, derivative duty, owed to his family, to reduce his personal spending to make ends meet given the increase in his business expenditure. By hypothesis, Albert comes to have the legal duty to purchase the new, more costly program because, once the new legislation is factored in institutional practice, that is what principled consistency in the practice now dictates. On this basis, we can say that the duty obtains because of the difference that the legislation properly made to the law. On the other hand, Albert comes to have some duty of financial prudence because of the effect of these developments on Albert's finances, together with certain personal circumstances and standing obligations that seem unrelated to the subject matter of legislation and to the principles that govern it. On these facts, there is no reason to suppose that this duty bears the right relation to institutional practice, as that was changed by the legislation, which would qualify it is as genuine legal duty whose recognition and enforcement would serve principled consistency. We have no basis, in this case, to say that the duty was due to the difference that the legislation properly made to the law - though it remains possible that the effect of the difference the legislation did make on Albert's finances might bear on some aspect of antecedent legal rights or duties that he might have such as a duty of child maintenance.

\section{DISAGREEMENT}

The fundamental assumption that ties enforcing rights and obligations to institutional practice serves to fix the subject matter of inquiry by setting the interpretative problem. Notice however that it does not rise to a conceptual constraint as these are normally understood. For the theory treats it as a commonly held moral hypothesis about the normative relevance of institutional practice. As a substantive hypothesis it is not immune to doubt but is subject to 
critical scrutiny. It would remain possible coherently to reject the assumption as mistaken, as long as an alternative hypothesis could make intelligible other common pre-theoretical commitments. The doctrine that Dworkin ${ }^{39}$ calls "pragmatism" illustrates this possibility, since it rejects the dependence of permissible enforcement on legality as defined above, and recommends instead that claims of obligation be enforced when doing so is justified by forward looking considerations. For the pragmatist, the claims' relation to institutional practice is to be invoked merely for strategic purposes. We might say that the assumption that connects enforcement to institutional practice fixes but does not determine the subject matter of legal theory. Moreover, the basic assumption does not by itself entail an answer to the interpretative problem that it sets. That is the problem of constitutive explanation with which we began: how institutional practice figures in the constitutive determination of legal rights and obligations.

This picture requires that it be possible to share a subject matter without sharing truths that define it. Interpretivism about law implies the possibility of disagreement about the grounds of law, because it makes law's constitutive explanation a matter of substance - specifically, a matter of the moral justification of the role of institutional history in the determination of rights and obligations. Notice that the possibility of disagreement about grounds is implied not only by the controversial nature of morality, but already by the substantive (therefore potentially controversial) character of the grounds. If the question of grounds is substantive, we can disagree about what they are without changing the subject. Unsurprisingly, this is the issue with which Dworkin begins Law's Empire. ${ }^{40}$

One way to make out the possibility of disagreement about grounds that interpretivism implies is to show that disagreement of that character obtains. Dworkin said that disagreement about the grounds of law is pervasive. Many of his critics objected that the kinds of disagreement that Dworkin seemed to have in mind can be explained in a way other than as disagreements about grounds: for

39 Dworkin (n 2).

40 Dworkin (n 2). 
NICOS STAVROPOULOS

example, disagreements about the social facts that constitute legal norms, or about how to apply the norms, or about how to decide cases where the norms run out (therefore how to extend the law), against a background of agreement on the grounds of law. ${ }^{41}$

Another strategy is to show the possibility of such disagreement directly, by offering arguments against the view that it must be impossible.

The first strategy is unlikely to be productive. (Notice that some theorists nonetheless think the strategy important to the defense of interpretivism). ${ }^{42}$ The interpretivist might begin by considering judgments about the existence of some legal obligation. His critics will say that disagreement in such judgments conceals agreement on grounds. The interpretivist will say that agreement in such judgments conceals disagreement on grounds. Absent some demonstration that actual agreements and disagreements are of one or the other kind, it will be hard to resolve the issue. It is possible instead to construct an inference to the best explanation of the phenomena, and the interpretivist may press that line, but, as I will suggest, the success of his thesis does not depend on the outcome.

The second strategy addresses what really matters for interpretivism. It may be that all lawyers agree on the grounds of law. That would be consistent with it being a matter of substance what the grounds are: perhaps lawyers just happen to concur in their judgments. What the interpretivist needs to show is that to challenge the consensus would not be to change the subject. He needs to show that disagreement about grounds is on the cards.

To defend the claim that disagreement about grounds is indeed possible, one would have to resist the assumption that, as a general matter, we can only share a subject matter by sharing truths that define it. Indeed Dworkin, anticipating that his examples of disagree-

41 Brian Leiter, 'Beyond the Hart/Dworkin Debate: The Methodology Problem in Jurisprudence' (2003), 48 American Journal of Jursiprudence 17; Scott Shapiro, 'The 'Hart-Dworkin' Debate: A Short Guide for the Perplexed', in A. Ripstein (ed), Ronald Dworkin (Cambridge University Press 2007), though not a defender of interpretivism, finds such responses unsatisfactory.

42 See Dale Smith, 'Theoretical Disagreement and the Semantic Sting' (2010), 30 Oxford Journal of Legal Studies 635. 
ment that appears to be about grounds would be reinterpreted by his critics as disagreement about social facts or about how to change the law, invited his critics not to rule out the possibility that disagreement might be more fundamental. He said that to think that disagreement about grounds is never possible, for the reason that to share a subject matter we must share criteria that define it, is a philosophical prejudice: he called the prejudice "the semantic sting". 43

It is now a familiar claim in general philosophy that, in the case of certain objects and phenomena, an account of their nature is not built into the understanding of the words that refer to them that is sufficient for competent use of the words (or into the understanding of the relevant concepts that is sufficient for competent thinking about the objects). Such understanding, captured in criteria of application and truths shared among competent users, does not provide sufficient metaphysical guidance. In many cases, that understanding includes an open-ended clause that allows for the existence of a certain kind of explanation of the nature of the objects, or, at least, that understanding does not rule out some such explanation, yet certainly falls short of picking out any particular explanation from among the eligible ones. In such cases, substantive investigation is indispensable to a complete explanation of the nature of the relevant object, and often must come first, before we realize that it is indeed germane to the nature of the object. ${ }^{44}$

Now if it is granted that the explanation of the nature of some objects may turn on matters of substance, the interpretivist may defend the view that judgments about the grounds of law are open to challenge. For he can simply construct such a challenge explicitly as one that disputes that the considerations that are generally regarded to be the grounds of law are indeed such grounds. ${ }^{45}$

43 See Dworkin (n 2).

44 Saul Kripke, Naming and Necessity (Blackwell 1980); Tyler Burge, 'Intellectual Norms and Foundations of Mind' (1986), 83 Journal of Philosophy 697; Georges Rey, 'What Implicit Conceptions Are Unlikely to Do” (1998), 9 Philosophical Issues 93; Williamson, Timothy (ed), "Epistemological Conceptions of Analyticity", in The Philosophy of Philosophy (Blackwell 2007); Stavropoulos, Nicos, Objectivity in Law (Clarendon Press 1996), (n 3).

45 Cf Burge's strategy in Burge (n 44). 
It is easy for the interpretivist to pursue that strategy. He can show that there exist different eligible and mutually inconsistent candidates for legal relevance. Do achievement intentions of legislatures (intentions to change the law in a certain way) play any role in the explanation of the impact of a statute? If so, do they play a constitutive or merely an evidentiary role? Do expectations that some arrangement introduced by statute will persist ever play some role in the explanation of the statute's impact? If so, do such expectations, even if formed in the face of explicit notice to the contrary, prevent later legislation from radically changing the original arrangement (cf. National Federation of Independent Business v. Sebelius 567 US (2012) (11-393), opinion of the court), or is their legal relevance extinguished by the explicit notice ( $c f$. National Federation of Independent Business v. Sebelius, Ginsburg, dissenting)? As we already saw in section 4, institutional practice includes countless examples of such inconsistent eligible candidates, each eminently defensible as legally relevant. But suppose that almost all lawyers agree on the relevance of one of a pair of inconsistent candidates. The fact that they do is yet another aspect of the practice, which is not privileged. For the interpretivist, substantive - moral- considerations serve the purpose of determining the relevance of any factor. On the basis of such considerations, he can argue that the unpopular candidate is in fact relevant so the lawyers' consensus is mistaken.

This view traces the intelligibility of fundamental challenges about the grounds of law to unusual moral views about the legal relevance of some factor. If this is correct, we should expect that such challenges may occur with some regularity, and that arguments once widely considered not colorable may come to be taken seriously and finally to become dominant. The quick transition, from nonstarter to endorsement by the US Supreme Court, of the view that the Constitution limits legislative authority to regulate private civilian uses of firearms (District of Columbia v. Heller, 554 US 570 (2008) (07-290)), or of the view that the regulatory powers of the federal government do not extend to mandating the purchase of health insurance ( $\mathrm{Na}$ tional Federation of Independent Business v. Sebelius, cited above), are recent illustrations. 


\section{BIBLIOGRAPHY}

Brink D, 'Legal Interpretation and Morality', in Leiter B (ed), Objectivity in Law and Morals (Cambridge University Press 2001).

Burge T, 'Intellectual Norms and Foundations of Mind' (1986), 83 Journal of Philosophy: 697.

Burley J (ed), Dworkin and His Critics: With Replies by Dworkin (Blackwell 2004).

Cohen M (ed), Ronald Dworkin and Contemporary Jurisprudence (Duckworth 1984).

Coleman J, The Practice of Principle (Oxford University Press 2001).

Coleman J (ed), Hart's Postscript (Oxford University Press 2001).

Correia F and Schnieder B (eds), Metaphysical Grounding: Understanding the Structure of Reality (Cambridge University Press 2012).

Christiano T, "Authority", in Zalta Edward N. (ed), The Stanford Encyclopedia of Philosophy (Spring 2013 Edition), http://plato. stanford.edu/entries/authority/.

Draghi M, “Speech", President of the European Central Bank, Global Investment Conference in London 26 July 2012. Available at <http://www.ecb.europa.eu/press/key/date/2012/html/ sp120726.en.html>.

Dworkin R, Taking Rights Seriously (Duckworth 1978). Relevant sections include "The Model of Rules I" (Ch. 2), "The Model of Rules II" (Ch. 3), "Hard Cases" (Ch. 4), "Reply to Critics" (Appendix).

Dworkin R, "Natural Law Revisited" (1982), 34 University of Florida Law Review 165.

Dworkin R, "My Reply to Stanley Fish (and Walter Benn Michaels): Please Don't Talk about Objectivity any More", in Mitchell WJT (ed), The Politics of Interpretation (University of Chicago Press 1983).

Dworkin R, 'A Reply to Critics' in Cohen Marshall (ed), Ronald Dworkin and Contemporary Jurisprudence (Duckworth 1984). 
Dworkin R, A Matter of Principle (Harvard University Press 1985). Relevant sections include 'Political Judges and the Rule of Law' (Ch. 1), 'The Forum of Principle' (Ch. 2), 'Principle, Policy, Procedure' (Ch. 3), 'Is there Really No Right Answer in Hard Cases?' (Ch. 5), 'How Law is Like Literature' (Ch. 6), 'On Interpretation and Objectivity' (Ch. 7).

Dworkin R, Law's Empire (Harvard University Press 1986).

Dworkin R, 'Objectivity and Truth: You'd Better Believe It' (1996), 25 Philosophy and Public Affairs 88.

Dworkin R, 'Comment' in Antonin Scalia (ed), A Matter of Interpretation: Federal Courts and the Law (with commentary edited by Amy Gutmann, Princeton University Press 1998).

Dworkin R, Justice in Robes (Harvard University Press 2006). Relevant sections include 'Hart's Postscript and the Point of Political Philosophy' (Ch. 6), 'Thirty Years On' (Ch. 7), 'The Concepts of Law' (Ch. 8).

Dworkin R, Justice for Hedgehogs (Harvard University Press 2011). Especially 'Law' (Ch. 1).

Fine K, 'A Guide to Ground' in Correia F and Schneider B (eds), Metaphysical Grounding (Cambridge University Press 2012).

Finnis J, Natural Law and Natural Rights (Oxford University Press, 1980).

Finnis J, 'On Reason and Authority in Law's Empire' (1987), 6 Law and Philosophy 357.

Finnis J, 'Law as Co-ordination' (1989), 2 Ratio Juris 97.

Finnis J, 'Natural Law and Legal Reasoning', in George R (ed), Natural Law Theory (Clarendon Press 1992).

Gardner J, 'How Law Claims, What Law Claims' in Klatt M (ed), Institutionalized Reason, The Jurisprudence of Robert Alexy (Oxford University Press 2012).

George R (ed), Natural Law Theory (Clarendon Press 1992).

Greenberg M, 'How Facts Make Law' (2004), 10 Legal Theory 15798. Available online <http://papers.ssrn.com/sol3/papers. cfm?abstract_id=797125>. 
Greenberg M, 'The Prism of Rules' (2007) UCLA School of Law Research Paper No. 07-31, available online at <http://papers. ssrn.com/sol3/papers.cfm?abstract_id=1042121>.

Greenberg M, 'The Standard Picture and Its Discontents' in Green, Leslie and Leiter, Brian (eds), Oxford Studies in Philosophy of Law, vol. 1 (Oxford University Press, 2011).

Greenberg M, 'Legislation as Communication' in Marmor Andrei and Soames Scott (eds), Philosophical Foundations of Language in the Law (Oxford University Press 2011).

Hart HLA, Essays on Bentham (Clarendon Press 1982).

Hart HLA, The Concept of Law (2nd edn, Clarendon Press 1994).

Hershovitz S (ed), Exploring Law's Empire (Oxford University Press 2006).

Hershovitz S, 'Integrity and Stare Decisis' in Exploring Law's Empire (Oxford University Press 2006).

Kelsen H, Principles of International Law (Rinehart \& Co. 1952).

Kripke S, Naming and Necessity (Blackwell 1980).

Leiter Brian, 'Beyond the Hart/Dworkin Debate: The Methodology Problem in Jurisprudence’ (2003) 48 American Journal of Jursiprudence 17.

Leiter Brian, Naturalizing Jurisprudence: Essays on American Legal Realism and Naturalism in Legal Philosophy (Oxford University Press 2007).

Mitchell WJT (ed), The Politics of Interpretation (University of Chicago Press 1983).

Nagel T, ‘The Problem of Global Justice' (2005) 33 Philosophy \& Public Affairs 113.

Raz J, The Concept of a Legal System (2nd edn, Clarendon Press 1980). Raz J, 'Legal Principles and the Limits of Law' (1972) 81 The Yale Law Journal 823; reprinted in Cohen, 1984.

Raz J, Practical Reason and Norms (2nd edn, with Postscript, Princeton University Press, 1990, originally published London: Hutchinson 1975). 


\section{NICOS STAVROPOULOS}

Raz J, 'Dworkin: a New Link in the Chain' (1986) 74 California Law Review 1103.

Raz J, Ethics in the Public Domain (Clarendon Press 1994).

Raz J, 'Two Views about the Nature of Law' in Coleman Jules (ed), Hart's Postscript (Oxford University Press 2001).

Rey G, 'What Implicit Conceptions Are Unlikely to Do' (1998) 9 Philosophical Issues 93.

Ripstein A (ed), Ronald Dworkin (Cambridge University Press 2007). Scalia A, A Matter of Interpretation: Federal Courts and the Law (with commentary edited by Amy Gutmann, Princeton University Press, 1998).

Schauer F, 'Positivism as Pariah' in George RP (ed), The Autonomy of Law: Essays on Legal Positivism (Clarendon Press 1996).

Shapiro S, 'The 'Hart-Dworkin' Debate: A Short Guide for the Perplexed' in Ripstein A (ed), Ronald Dworkin (Cambridge University Press 2007).

Smith D, 'Theoretical Disagreement and the Semantic Sting' (2010)

30 Oxford Journal of Legal Studies 635.

Stavropoulos N, Objectivity in Law (Clarendon Press, 1996).

Stavropoulos N, 'The Relevance of Coercion: Some Preliminaries' (2009) 22 Ratio Juris 339.

Stavropoulos N, 'Obligations and the Legal Point of View' in Marmor A (ed), The Routledge Companion to Philosophy of Law (Routledge 2012).

Stavropoulos N, 'Words and Obligations' in Dolcetti A, Duarte

d'Almeida L and Edwards J (eds), Reading HLA Hart's 'The Concept of Law' (Hart Publishing 2013).

Williamson T (ed), 'Epistemological Conceptions of Analyticity' in The Philosophy of Philosophy (Blackwell 2007).

\section{ACKNOWLEDGMENTS}

I presented drafts of this entry at Pompeu Fabra University, Department of Law, and at the University of Michigan, Department of Phi- 
losophy. I am grateful to participants at these events for valuable discussion. I was greatly helped by comments on earlier drafts by Scott Hershovitz, Leslie Green, Liam Murphy, Dale Smith, and, especially, Scott Shapiro, and by many discussions with Mark Greenberg over the years on some of the topics discussed in this entry. 